Everywhere your ambassador was met with the greatest courtesy and friendliness. It is not easy to convey in words how much I appreciate the whole-hearted welcome given me in our big southern continent. The kindness and urbanity meted out to me, and to my son who accompanied me, were generously and spontaneously given wherever we went-in the Government Houses, the Residencies, where we were received as honoured guests (Sir Alexander MacCormick acted right royally for the late Governor-General of New South Wales), and in the homes of our medical colleagues, where wo were privileged to join the family group-made one feel very keenly the strength and spirit of the family ties which bind Britons together.

Not only were we welcomed by the medical profession but by many of the most distinguished members of the laitythe Prime Ministers, Chancellors and Professoriate of the Universities, by judges, merchants, and also many of the more humble classes. I may quote the letters of the Prime Minister of New South Wales as example.

Dear Sir WILLIAM MACEWEN,

$$
\text { New South Wales, }
$$

Premier's Department, Sydney.

I am directed by Sir George Fuller to enquire, following the call of his representative upon you last week, if there is anything he can do to make your stay in New South Wales a pleasant and instructive ple your own profession will be straining every nerve to do you honour, but would himself like to be able to find some means of serving you on his own behalf, and on-behalf of the State. He would be glad to arrange for you to be aceommodated with railway or other facilities to enable you to see some of the points of interest and beauty of New South Wales, and if you would be good enough to let me know your desires in this direction, I shall be pleased to make the necessary arrangements. Yours faithfully, CLIFFord H. HAY

October 22nd, 1923. Sccretary.

\section{New South Wales}

Premier's Department, Sydney.

Dear Dr. ToDD

Mr.Hay has shown me your letter of 30th October conveying Sir William Macewen's appreciation of the courtesy shown him. by the Government in affording him facilities to visit the Blue Mountains and Jenolan Caves. In making grateful acknowledgement of your letter, I desire to state that it afforded me, personally, very great pleasure to be able to show Sir William Macewen some little attention as a distinguished visitor to our State. I trust I shall have the pleasure of meeting him in Melbourne next week.

$$
\begin{aligned}
& \text { Yours faithfully, } \\
& \text { GEORGE U.' FuLLER, }
\end{aligned}
$$
Premier.

November 2nd, 1923

Among the many other testimonies of goodwill I encountered I will mention only the official welcome extended to me
by the Sydney University Medical Society in the Great Hall of the University on October 19th. Speeches were made by the President of the Society (Dr. R. A. Money), the Dean of the Faculty of Medicine (Professor Mills), and the Professor of Surgery (Professor Sandes), who did me the honour of saying that I had always taken a kindly interest in the students. In my reply I thanked the audience for the enthusiastic welcome they had accorded to me, and said that the students and I had always been friends, and added that I would always regard myself as a student. I concluded by paying a tribute to the Australians for their part in the war, saying that it had made manifest the unity of the British race in a critical hour.

Through the great kindness and goodwill of many of the leading business men, statesmen, and merchants I had an opportunity of gaining an insight into the commercial, industrial, and financial conditions of Australasia and a first-hand information into the politics and aspirations of the statesmen of the Commonwealth. I thus had a unique opportunity of learning the views of most parties and of making deductions therefrom.

The country, its magnificence, its vastness, the beauty of its flora, and its rich and altogether its extraordinary fauna, were a never-ending source of wonderment. The eucalyptus alone among plants, the marsupials of all kinds from mankangaroos to mice, and its most brilliantly coloured birds and their cries, made one wish to have another life to live.

I have to thank the Council for giving me the opportunity of visiting one of the most wonderful countries in the world-a country which has been opened up by the intrepidity of our early explorers-and the vast strides our kinsmen have made in the way of settlement and civilization within eighty odd years is not the least of its wonders.
The Australians are great people, strong, vigorous, and independent, and are endowed with unbounded generosity and kindness.

Sir William Macewen also referred to the extraordinarily kind reception he had received in New Zealand, where the hospitality was on the same generous pattern as in Australia. $\mathrm{He}$ was most kindly received by the Governor-General, Admiral Viscount Jellicoe, and he must also acknowledge the welcome which he received on behalf of the members in New Zealand from Dr. W. E. Herbert, Chairman of the New Zealand Branch Council. He attended a quite enthusiastic meeting in the Dominion, and was the guest at a banquet afterwards.

On reviewing his whole tour there were two names which he wished to mention with special gratitude. One of these was Dr. A. L. Kenny of Melbourne, the general secretary of the Australasian Medical Congress, and the other Dr. R. H. Todd, honorary secretary of the New South Wales Branch.

At the conclusion of Sir William Macewen's report, the Chairman of Council (Dr. R. A. Bolam) said that the Council was deeply grateful to Sir William Macewen for acting as ambassador of the Association on the other side of the world. Australia and New Zealand had certainly welcomed him with the cordiality he deserved. The Chairman felt confident the Council would wish to place on record its sense of the great service which Sir William Macewen had rendered to the Association in the course of this tour, and its pleasure in the fact that he had returned safely, looking very much better for his trip. (Applause.)

Dr. A. Lyndon suggested that a letter be sent to the honorary secretary of the New South Wales Branch, thanking him and requesting him to convey. the thanks of the Council to his members and to all concerned for the hospitality shown to the representative of the Association.

This was agreed to.

\section{ALCOHOL: ITS USE AND ABUSE. LADY PRIESTLEY MEMORIAL LECTURE.}

BY

\section{W. E. DIXON, M.D., F.R.S.}

The Lady Priestley Memorial Lecture, arranged by the National Health Society, was delivered at the house of the Royal Society of Medicine, on February 18th, by Professor W. E. Drxon, M.D., F.R.S., whose subject was "Alcohol: its use and abuse."

Sir James Crichton-Browne, who presided, said that he supposed there was no subject, outside religion, about which there had been more heated and acrimonious controversy than alcohol. Misrepresentations, exaggerations, contradictions, and delusions had swarmed in this field. On the one hand, alcohol had been extolled as the elixir vitae, and on the other denounced as a deadly poison. It was neither one nor the other, but a good gift to man, susceptible, like other gifts, of gross abuse, but capable also of inestimable service when properly employed.

\section{The Growth of Temperate Habits.}

Professor Drxon, after showing how the habits of eating and drinking had arisen out of human experience and instinct, said that the drink habit had undoubtedly served its purpose in the past; it was one of the many forms of individual protection resorted to by nature to save men from diseases associated with the herd instinct. Dr. William Mayo had said that in France and Italy the consumption of billions of gallons of wine had saved the people from extinction; they could not have lived had they drunk their polluted water. In modern Vienna, when a pure water supply from the mountains was substituted for a contaminated one from other sources, the consumption of alcoholic beverages was reduced by 40 per cent. With the growth of hygiene the necessity for alcohol from this point of view ceased to exist; though the custom of drinking alcoholic beverages remained. Most countries, however, showed a considerable reduction in such consumption. He indicated the immense fall in consumption per head of population which had taken place in this country since the eighteenth and early nineteenth century. As to 
the recent decline in other countries, he gave some figures for France, where, between 1913 and 1921, the consumption of alcohol for beverages had diminished by more than 50 per cent., though wine during those years had shown some increase at the expense of spirits. This diminution was due, partly at least, to legislation and enforced economy, and not solely to moral ideals. In Belgium also a 50 per cent. reduction in the consumption of alcoholic beverages was shown in recent figures compared with those for 1910. With regard to America there had been a diminution in drinking, though statistics were at variance. The so-called "boot-legging" was common in some parts of the States, and some American journals were protesting that the physician had taken the place of the bar tender. In an analysis of 1,000 cases the reasons given by American physicians for prescribing alcohol were: bronchitis in 354, general debility in 167, " la grippe " in 163, while other conditions offering similar excuse were boils, colds, diabetes, eye-strain, and headaches. He would not suggest that this was usual or even common with the American physician; a few physicians who prescribed freely might satisfy a good many people. But, on the general question, he thought it would be accepted that throughout the civilized world there was, and had been for some time, a growing tendency towards moderation and temperance, and, further, that either the most objectionable results of drinking must be eliminated by reform, or almost any educated and intelligent public would encourage some form of prohibition.

\section{The Function of Alcohol.}

The lecturer went on to speak of the wide distribution of alcohol throughout nature, always in association with living cells. In man both yeasts and the Bacillus coli communis formed it in the alimentary canal, and as it was one of the most easily absorbed of all substances it must be taken up directly into the system. Three important facts about alcohol might be regarded as established. The first was that alcohol was very rapidly absorbed from the stomach and intestines into the tissues, where it was oxidized very slowly, and there it could be regarded as a food, in the sense that it spared the carbohydrates, fats, and proteins. The late M. Duclaux, of the Pasteur Institute, was so much impressed by the experimental evidence on this question that he asserted that alcohol was a food surpassing starch and sugar in alimentary value, since weight for weight it contained more energy. The second fact about alcohol was its so-called stimulant action on the central nervous system: mental operations were shortened, simple reaction times quickened, mental associations (such as making words to rhyme) facilitated, reading in whispers rendered easier, and the appreciation of small differences in weights enhanced. The view that all these effects were due to direct stimulation of the central nervous system, as in the case of caffeine or cocaine, might be regarded as disproved; they were due to a direct depression, beginning with the activity of the higher faculties of the mind. The activity of these faculties was blunted, and the real person was liberated from the bondage of those restraints which social customs and conrentions demanded. Alcohol freed the primitive instincts and emotions. For all precise mental operations the use of alcohol was detrimental, whether in typewriting, target pricking, typesetting, shooting, choice reactions, and the like; it diminished accuracy and speed. Alcohol was an artificial means of relaxation; under its influence the burdens, anxieties, and worries of the modern strenuous life were forgotten. The sociability produced by the flowing bowl, as described in picturesque writings, was really due to the diminished irritability of a supersensitive nervous system. The third fact about alcohol which appeared to be generally accepted was that in conditions of fatigue and mental depression alcohol acted as a true stimulant in that certain faculties of the mind, such as attention and memory, were improved. The lecturer indicated the possible value of alcohol to a mental worker returning home to dinner, irritable and overwrought, after a strenuous day, and unable to take an interest in his food. Physiologists were aware that appetite and digestion were largely in- fluenced by the mind. If worry and anxiety were removed, appetite and digestion would return. It might, therefore, almost be said that apéritifs were physiological under present-day conditions, were it not for the fact that they were so of ten consumed by the wrong people. But in spite of these and other useful functions, the evidence was clear that alcohol was not a necessity for a healthy man; it was a luxury, and an expensive way of taking food. On the other hand, when it was taken in strict moderation, injurious effects had yet to be proved.

\section{Social Effects.}

This was not, of course, the entire balance sheet. Thousands of people were reduced to poverty, misery, and disease, and were provoked to commit crime as a result of excessive drinking; on the other hand, millions of people stated that alcohol added to the joy and general agreeableness of life. Social workers and physiologists from time to time arranged and annotated the evidence for and against alcohol, and placed it before the public. He thought that everyone should be grateful for such reviews, because truth came first, even before the principles one had been accustomed to advocate. But in this connexion it might be interesting to note what the publican, who had an interest in the elimination of drunkenness, thought to be the most frequent causes of that condition. In an inquiry among London publicans the following were given as the principal reasons for drunkenness: irregular feeding, intensive drinking during shorter hours of trade, discomfort of home life and domestic troubles, mistaken kindness of friends. It was generally agreed by these close, if not unbiased, observers that food was the solution of the problem. The publicans said that foreigners, including Jews, rarely got drunk, because they ate while drinking.

\section{The Problem of the Alcoholic.}

The most important class of drinkers had yet to be cont sidered-namely, the alcoholics, the group which had created the drink problem. It was important to learn something of the nature of the desire which impelled the alcoholic to take alcohol. One of the most drastic prohibitions ever attempted in history was the Harrison Narcotic Law, and after a trial of eight years it was the universal opinion of those best able to judge that the law had signally failed in its purpose. He believed the explanation to be that ton little thought was given to the nature of the addicts, and all the consideration was concentrated on the drugs. The word "alcoholism" was sometimes too widely used; it should be strictly analogous to " morphinism" and "cocainism." Alcoholism used in this sense was not drunkenness nor the habit of drinking, even occasionally to excess. The normal man, after taking alcohol, became in certain respects abnormal. The alcoholic, on the other hand, took alcohol because he needed it if he was to become normal. He was a neurotic, to whom every common incident of lifo was exaggerated. Alcohol gave him temporary relief from his inertia and depression. Alcoholism was regarded by many eminent authorities as a symptom of a pre-existing mental condition. In the early stages the alcoholic resisted the craving, but soon, whenever he felt depressed, his one thought was drink. The mental physician must determine how best to treat the neurotic, but it was well to remember that the neurotic type of alcoholic was precisely the same type of person who, if opportunity offered, would take to drugs; temporarily this gave him the relief that alcohol gave, and after once partaking of the joys of the hypodermic needle he practically never returned to alcohol. While there were such people in our midst it was of the utmost importance that any steps to ensure temperance should be taken with great forethought and circumspection. In this connexion Professor Dixon pointed out an evil which had already arisen merely from the high price of alcohol-namely, the use of methylated spirits, either for drinking alone or for mixing with wine or beer. The habit of drinking this spirit was particularly prevalent in Scotland. The lesson he drew from this was that if this country suddenly adopted prohibition there was little doubt from what source some people would obtain their supply of alcohol. By study and experiment it 
should be possible to produce a spirit sufficiently nauseating to prevent its imbibition without interfering with its' commercial value. He also touched on the dangers arising from illicit liquor traffic in prohibitionist countries or countries in which the supply of alcohol was greatly diminished. In America inebriety was less prevalent than a few years ago, but when it occurred its effects were far more serious. This was most likely due to " moonshine" liquors, which were improperly manufactured and contained methyl alcohol and poisonous aldehydes. In America, from the beginning of prohibition to the end of 1919,255 deaths had been reported from poisoning by a substance generally believed to be methyl alcohol, and there must have been at least one hundred cases of blindness following the use of wood alcohol. Similar tragedies, though in smaller degree, were found in other prohibition countries. Thus Blegvad of Denmark had seen 32 cases in the last year or two in which central amblyopia sooner or later supervened after the daily drinking of kogesprit in place of the more expensive brandy. "Rostedt stated in 1921 that since the complete prohibition of alcohol in Finland cases of eye injury from substitutes for brandy totalled 60. In England large quantities of methyl alcohol or wood spirit were used for varnishes, and unconsidered drastic legislation in this country would certainly not be free from very grave dangers along these lines.

\section{The Need for Education.}

The answer to the alcohol problem was not prohibition, but, in a large measure, education. Unfortunately, the educational methods on this subject hitherto employed left much room for improvement; they savoured of political contests and bias. Some of the pamphlets and books on the scientific aspects of alcohol were grossly inaccurate, and a number were even nonsensical. The propaganda of the local option contests recently concluded in Scotland supplied abundant examples of inaccuracies of every description. An educational campaign such as this was misleading and did harm. A proper educational campaign required to be guided by science. Personal prejudices and interests must be ruthlessly disentangled from moral argument. Among other misstatements he mentioned the common allegation that cirrhosis was always caused by alcohol. Cirrhosis of the liver was very frequently associated with alcohol, though alcohol was not the direct cause of this condition, and various authorities mentioned a proportion of one-quarter to one-half of the total number of cases of cirrhosis as being due to or associated with alcohol. One disgraceful state of affairs still required solution, especially in the larger citiesnamely, the condition of the public-houses.' These must not be allowed to remain as mere drinking palaces. Their place must be taken by decent houses of recreation and refreshment in which all people might meet in a reasonable and friendly manner.

Altogether, while he admitted that the result of America's vast experiment had yet to be recorded, Professor Dixon did not believe that prohibition would accomplish what its advocates claimed for it. Certainly prohibition had nothing to do with self-control, and equally, of course; nothing to do with education.

\section{Divergent Views on Prohibition.}

Sir HuMphry Rolleston, P.R.C.P., in proposing a vote of thanks, said that the lecturer had enabled the audience to see both sides of the shield-both the uses and the abuses of alcohol. He feared that every person approaching such a subject as this was biased by his own impressions, but Professor Dixon had shown at least how complex was the problem and how difficult it was to form any dogmatic opinion. If, on the one hand, the effect of alcohol was observed on the amoeba there could be no doubt at all that alcohol was a protoplasmic poison; but not only did man differ from lower forms of life, individual men differed from one another, and in this imperfect world there were numbers of people who, from heredity or circumstance, were in absolute need of some kind of narcotic. These people, if denied alcohol, would take to some other narcotic, most probably more harmful.
Bir Thomas Horder, Bt., in seconding the vote of thanks, remarked on the difficulty of making any positive affirmations or denials on this subject, and gave an amusing instance out of his recent experience. He was asked if there had been any experiments, carefully devised, the conclusions of which proved that the taking of alcoholic beverages in moderation was injurious to health. To this he had replied "No," and unhappily his reply, which was published, was taken to mean that he sympathized with intemperance. A month later he was rung up at 2.30 in the morning by a sergeant at the Harrow Road police station, who said that he did not know whether he would think it necessary to come to the station, but a man had been brought in and charged with being drunk while in charge of a motor lorry, and had stated that the doctor he wanted to see was Sir Thomas Horder! With regard to prohibition in America, the speaker thought that it was not understood in this country exactly what kind of situation the United States had to face. Prohibition was introduced primarily to get rid of the gin palace, which was a terrible evil, and an institution to which in this country we had no parallel. National health demanded that at all costs these gin palaces should be shut up; and whatever prohibition had or had not done, it had effected a great improvement in this respect.

Dr. Charles Ponter (M.O.H. Marylebone), who had lately returned from a visit to the United States, said that he had come to the conclusion that prohibition was the finest thing that the United States had yet done. The evils, such as "boot-legging," which it was supposed prohibition had brought in its train, were not of such dimensions as some people over here would like them to believe. The hospital admissions of alcohol cases had, of course, increased, but these cases, in the pre-prohibition era, would have spent the night at the police station; as it was they were generally discharged from the hospital the next day. He had spoken to many people in the United States wlio held various views on the general subject, but the feeling among all of them was of immense relief that the saloon had disappeared. Employers of labour were loud in their praises of prohibition because it was reflected in betterkept time sheets and in increase of efficiency on the part of the workmen. The health visitors also expressed the strong opinion that the condition of the homes of the people had very greatly improved since prohibition came in, and as a medical officer of health it was in this sociological aspect of the question that he was chiefly interested. After studying it at first hand he felt that American prohibition was one of the most valuable experiments ever performed by any nation, and he deprecated an attitude of criticism, still more an attitude of ridicule.

Dr. Arthur Shadwenc referred to the present inadequacy of scientific conclusions, and said that what was known scientifically about the action of alcohol was as nothing to what remained still unknown. On the other hand, Professor H. E. Armstrong, who spoke as a chemist, said that, however much might yet remain for science to do or to discover, it had ensured for this country and for other nations of Western Europe a safe water supply, and this had contributed more than any other single factor to eliminate the excessive use of alcohol with its attendant evils.

Sir James Crichton-Browne closed a brief but brisk discussion by quoting various physiologists, the latest of them Professor Starling, to the effect that in a society like ours the abolition of alcoholic beverages would be a mistake, and not to our permanent interests; and that, if made compulsory, such abolition would be a national calamity.

THE German Congress for Diseases of Digestion and Metabolism will be held on April 26th and 27th under the presidency of Professor von Bergmann of the Frankfort Medical Clinic, when the following subjects will be discussed : (1) Diseases of the pancreas, introduced by Geelen, Gulecke, Stepp, and Minkowski. (2) Gastric diseases following operations, introduced by $Z$ weig and Haberer. The place at which the congress will be held has not yet been settled. Further information can be obtained from the secretary, Professor Fuld; Uhlandstrasse 157, Berlin. 